\title{
AYURLOG
}

National Journal of Research in Ayurved Science

http://www.ayurlog.com

June- 2020 | Volume $08^{\text {th }} \mid$ Issue: $3^{\text {rd }}$

ISSN: $2320-7329$

\section{Role of jalapan in the samprapti and vidhi vihit jalapan in the management of prameha w.s.r. to type-II diabetes mellitus}

\author{
Anjali A. Deshpande ${ }^{1}$, Archana A. Kulkarni*2
}

1. M.D, Ph.D. ( Kayachikitsa ) Professor, E-mail: - leena1610@yahoo.in, Mob.No.: 9730069747

2. M.D, (Rog nidan) Professor

BSDT's Ayurved College, Wagholi, Pune, Maharashtra

*Corresponding author: archana.arukulkarni@gmail.com, Mob.No.:- 9422164367

\section{ABSTRACT:-}

Present

era

of

urbanization,industrialization

is

responsible for the stresssful, sendentary lifestyle that makes a person more susceptible to Diabetes Mellitus.The misconceptions about food consumption,indiscriminate intake of liquids are the causative factors of lifestyle disorders like diabetes.Ayurveda is the science which explains scientific process and general rules for the consumption of food through the aaharvidhivisheshayatana and aaharvidhividhan.It also highlights the effect of proper food consumption and effect of proper water intake on the body. An open labeled add on comparative clinical study was conducted in BSDT's Ayurved hospital.Thirty diagnosed patients of type II Diabetes mellitus were randomly selected from the OPD of kayachikitsa and enrolled into two groups. Role of jalapan in the samprapti of prameha and vidhi vihit (as per rules described in samhita) jalapan along with the vyadhipratyanik chikitsa were assessed in the management of prameha with special reference to type II diabetes mellitus. Nidanparivarjana is an essential part in the management of disease. It is observed that there is an association between jalapan and prameha and vidhi vihit Jalapan plays an important role in the treatment of prameha.

KEYWORDS: - Prameha,Type II Diabetes mellitus, Vidhi vihit Jalapan

\section{INTRODUCTION:-}

Now a day's Diabetes has become an epidemic having by and large a huge impact on people of all ages. It is the fastest spreading, non-communicable disease. 'Diabetes' the word has become so common that it is not restricted to clinics and hospitals but has reached to every individual, family, society etc. The statistical data put forth by the international Diabetes Federation gives an overview of the rise in number of Diabetes 
patients up to 101.2 million till 2030 . According to WHO Diabetes is predicted to become $7^{\text {th }}$ leading cause of death by year $2030{ }^{1}$

Present era of urbanization, industrialization is responsible for the stressful, sedentary lifestyle. The rapid dietary and habitual changes in lifestyle make a person more susceptible to Diabetes. The ignorance of current generation about healthy food habits and exercise is displayed through the weight gain, hormonal disturbances, hyper activeness, increase medicinal dependency, occurrence of newer diseases etc. The misconceptions about food consumption, the indiscriminate intake of liquids like water, tea, coffee, cold drinks, addiction of junk food, inclination towards the taste of food instead of its usefulness for health are the causative factors of lifestyle disorders like diabetes now a days.

Many people are consuming water due to constipation, acidity, obesity, thyroid problems and diabetes or just as a habit since long term. Overuse of media is responsible for the prevalence of water intake especially in morning hours and also in the whole day. Water intake is blindly followed irrespective of the feeling of thirst, disease, constitution, regular exercise, climatic conditions etc. We conveniently neglect and choose the easiest way of indiscriminate drinking of water as a good, healthy habit for healthy lifestyle. Drinking water in early morning is advocated concurrent to proper and regular exercise on complete digestion of previously taken food, proper bowel and bladder evacuation and with feeling of freshness while awakening.

Ayurveda is the only science which highlights the effect of proper food consumption on the body. The effects of water intake on the body as well as the effects of process and technique of water consumption were also highlighted by Ayurveda. ${ }^{2}$

Modern science emphasizes on the nutritional value of the food and energy requirements to the body in terms of deficiencies and calories. But Ayurveda describes on the basis of rasa, virya, vipaka, guna and karma of the dravyas. It also explains scientific process and general rules for the consumption of food through the "Aaharvidhivisheshayatana" and "Aaharvidhividhan" described in rasaviman adhaya of viman sthana of Charak Samhita. ${ }^{3}$ Ayurveda has given evidence of the existence of prameha since vedic period. Prameha is basically apathyanimityaj and santarpanothha vyadhi. ${ }^{4}$

The vikar vighatkar bhava-abhava are responsible for the prameha. ${ }^{5}$ The absence of contrast factors to the causative factors of the disease is also responsible for immediate, delayed or severe manifestation of disease. The lack of regular exercise, absence of timely and restricted diet, atyambupan, and sedentary life style are the influential causative factors. The kaphakar (kapha vitiating) ahara and vihara are the causative factors for prameha. ${ }^{6}$

According to Charka, kapha dosha which is vitiated by the drava guna and increased in quantity is the main culprit for the prameha. This vikalpa vishesh of kapha dosha is particularly seen in the samprapti of the prameha. The excess quantity of liquids and the drava, sheeta, guru, snigdha guna of liquid vitiate kapha dosha and further vitiates the meda, mansa, kleda, shrukra, shonita, vasa, majja, lasika, rasa,oja etc the dushyas of prameha. $^{7}$ 
This study is under taken with the perspective to find out the association and the effects of, incorrect techniques and time of water intake (jalapan) and prameha. The evaluation of effect of vyadhipratyanik chikitsa and vidhi vihit jalapan (water intake as per rules described in grantha) in prameha.

\section{AIM AND OBJECTIVES:-}

Aim:-To study the role of jalapan in the samprapti of prameha and effects of vidhi vihit jalapan in the management of prameha with special reference to type II diabetes mellitus.

\section{Objectives:-}

1) To evaluate the matra and sevan kala of the jala (time of water intake) in diabetic patients.

2) To assess association between the vidhi virahit jalapan (not as per rules from grantha) and effects of vidhi vihit jalapan as chikitsa (Nidanpariwarjan) with vyadhipratyanik chikitsa in prameha with special reference to type II diabetes mellitus.

\section{MATERIALS AND METHOD:-}

Thirty diagnosed patients of type II Diabetes mellitus presenting with the classical symptoms of prameha from the OPD of Ayurved hospital were randomly selected and enrolled for the present study. On the basis of inclusion and exclusion criteria the thirty patients were classified into two groups with fifteen patients in each group. Jalapanvidhi (process of water intake) in diabetic patients was assessed by using specially prepared questionnaire with special emphasis on the ushapana, bhojanapashyat jalapan, nishapan, atyambupan (total water intake per day), jalapan was assessed on the basis of kala and matra.

The patients from experimental group were subjected to vidhi vihit jalapan and vyadhipratyanik chikitsa (shamana aushadhi) and patients from control group were subjected to only vyadhi pratyanik chikitsa. In both the groups patients were subjected to continue the same antidiabetic allopathic treatment which they were taking as before.

Modifications regarding water intake on the basis of vidhi vihit jalapan were explained to each patient in experimental group and were reviewed at every followup. At the end of duration of sixty days both the groups were assessed on the basis of assessment criteria. The follow-ups were conducted after every fifteen days. The symptoms of prameha like prabhutamutrata, avil mutrata, nakta mutrata, pipasadhikya, hastapadataldaha, alasya, sarvanga gaurava, malavibandha were selected for the assessment. ${ }^{8,9}$ The biochemical parameters like fasting and postprandial blood sugar levels before and after the treatment of two months were evaluated.

\section{INCLUSION CRITERIA:-}

- Patients of either gender age between 30 to 70 years

- Patients having classical symptoms of prameha

- Patients of type II diabetes mellitus

- Recently diagnosed patients of type II diabetes mellitus by the criteria blood sugar level fasting >126 mg $/ \mathrm{dl}$ and post prandial $>200 \mathrm{mg} / \mathrm{dl}$

\section{EXCLUSION CRITERIA:-}

- Uncontrolled diabetes

- $\mathrm{K} / \mathrm{c} / \mathrm{o}$ acute complications like keto acidosis, diabetic coma, acute 
infections of the any part of the body.

- Pregnant and lactating woman

- Patients on insulin and steroid treatment

- Patients with any major systemic diseases

- $\mathrm{K} / \mathrm{c} / \mathrm{o}$ benign prostatic hyperplasia

\section{DESIGN OF THE STUDY:-}

Study Centre: - The study was carried at Kayachikitsa OPD in BSDT's Ayurved Hospital.

The study was open labeled add on comparative clinical study.

The present interventional study was conducted with experimental group underwent the vidhi vihit jalapan and vyadhipratyanik chikitsa. vyadhipratyanik chikitsa includes Arogyavardhini vati 500 $\mathrm{mg}$ and Madhusudan vati $500 \mathrm{mg}$ in vyanodan kal (twice a day) with warm water for 60 days, along with the antidiabetic allopathic treatment.

The control group underwent only vyadhipratyanik chikitsa, Arogyavardhini $500 \mathrm{mg}$ and Madhusudan vati $500 \mathrm{mg}$ in vyanodan $k a l$ (twice a day) for 60 days additionally to antidiabetic allopathic treatment.

In vidhi vihit jalapan patients were advised the following modifications. They were instructed to avoid the water intake especially in the early morning, immediately after the food intake and at the bedtime. Patients were also asked to avoid excess water intake, not to drink water without the feeling of thirst and avoid drinking of liquids frequently. Not to pour water directly into the mouth. Avoid drinking large quantity at a time. Use normal boiled water for drinking. Not to re-boil the water once boiled properly. Drink the water as per requirement to quench the thirst, not to control and reduce the water intake even after the feeling of thirst.

At every follow-up the suggested modifications about jalapan were monitored and reviewed. The association between the vidhi virahit jalapan and diabetes was evaluated. The effects of vidhi vihit jalapan and vyadhipratyanik chikitsa in diabetes were assessed on the basis of assessment criteria mentioned below.

The Madhusudan vati and Arogyavardhini vati used were procured from Atharva nature health care private limited, Pune.

Assessment Criteria: - Symptoms of Prameha, prabhuta mutrata, awil mutrata, nakta mutrata, pipasa, hastapadataladaha, alasya, gurugatra, malavibandha and blood sugar level

(F and PP) were assessed before and after two months. The symptoms considered for evaluation were graded as follows.

\begin{tabular}{|l|l|l|}
\hline Symptom & Frequency & Grade \\
\hline Prabhutamutrata & Less than 6 times per day & 0 \\
\hline & 6-8 times per day & 1 \\
\hline & 8 to 10 times per day & 2 \\
\hline & More than 10 times per day & 3 \\
\hline Awil mutrata & Clear and transparent urine & 0 \\
\hline & Transparent but with suspended particles & 1 \\
\hline & Turbid with slight precipitation & 2 \\
\hline
\end{tabular}




\begin{tabular}{|c|c|c|}
\hline & Homogeneous turbid mixture & 3 \\
\hline \multirow[t]{4}{*}{ Naktamutrata } & Nocturnal urination absent & 0 \\
\hline & Urination less than 2 times in night & 1 \\
\hline & Urination 2 to 4 times in night & 2 \\
\hline & Urination more than 4 times in night & 3 \\
\hline \multirow[t]{4}{*}{ Pipasadhikya } & No urge of thirst & 0 \\
\hline & Urge of thirst every 3-4 hours & 1 \\
\hline & Urge of thirst more frequently & 2 \\
\hline & Persistent urge of thirst & 3 \\
\hline \multirow[t]{4}{*}{ Hastapadataladaha } & Absent & 0 \\
\hline & Sometimes & 1 \\
\hline & Frequently & 2 \\
\hline & Persistent & 3 \\
\hline \multirow[t]{4}{*}{$\begin{array}{l}\text { Gurugatrata } \\
\text { (Sarvanga } \\
\text { Gaurava) }\end{array}$} & Absent & 0 \\
\hline & Sometimes & 1 \\
\hline & Frequently & 2 \\
\hline & Persistent & 3 \\
\hline \multirow[t]{4}{*}{ Alasya (Anutsaha) } & Absent & 0 \\
\hline & Sometimes & 1 \\
\hline & Frequently & 2 \\
\hline & Persistent & 3 \\
\hline \multirow{4}{*}{$\begin{array}{l}\text { Malavibandha } \\
\text { (Malam Kaye) }\end{array}$} & Absent & 0 \\
\hline & Sometimes & 1 \\
\hline & Frequently & 2 \\
\hline & Persistent & 3 \\
\hline
\end{tabular}

Assessment was performed on patient's response to the treatment on the basis of improvement in the classical symptoms of prameha. The improvement was categorized as below

\begin{tabular}{|l|l|}
\hline Improvement \% & Grade \\
\hline $\begin{array}{l}\text { Improvement } \\
\text { Im\% }-50 \%\end{array}$ & Unchanged \\
\hline $\begin{array}{l}26 \% \quad \text { Mild improvement } \\
\text { Improvement }\end{array}$ & \\
\hline $\begin{array}{l}51 \%-75 \% \\
\text { Improvement }\end{array}$ & $\begin{array}{l}\text { Moderate } \\
\text { improvement }\end{array}$ \\
\hline $\begin{array}{l}\text { 76\% - 100\% } \\
\text { Improvement }\end{array}$ & $\begin{array}{l}\text { Marked } \\
\text { improvement }\end{array}$ \\
\hline
\end{tabular}

\section{OBSERVATION AND RESULTS:-}

In this study thirty patients were selected from the OPD of Kayachikitsa, having commonly occurring symptoms of prameha. The maximum of the patients under the study were 17 male comprising of $56.66 \%$ and 13 female were $43.33 \%$. The data showed that maximum patients $53.33 \%$ were from age group 41 to 50 years, while $13.33 \%$ patients from age group 31 to 40 years, $26.66 \%$ patients from 51 to 60 years and $6.66 \%$ patients were from 61 to70 years of age. Occupation wise data shows maximum number of 
patients $46.66 \%$ were belongs to service class (sedentary work) and suffering from mental stress. Housewives were also found $33.33 \%$ having sedentary work, day sleep, mental stress and vishamashana. Teachers were $6.66 \%$, drivers were $10 \%$ and businessmen were $3.33 \%$.In the present study, data related to jalapan shows that ushapan was found $83.33 \%$, bhojanottar jalapan was $75 \%$, nishapan $50 \%$ and atyambupan $58.33 \%$ was observed. Graph displays percentage of hetu related with jalapana (water intake)

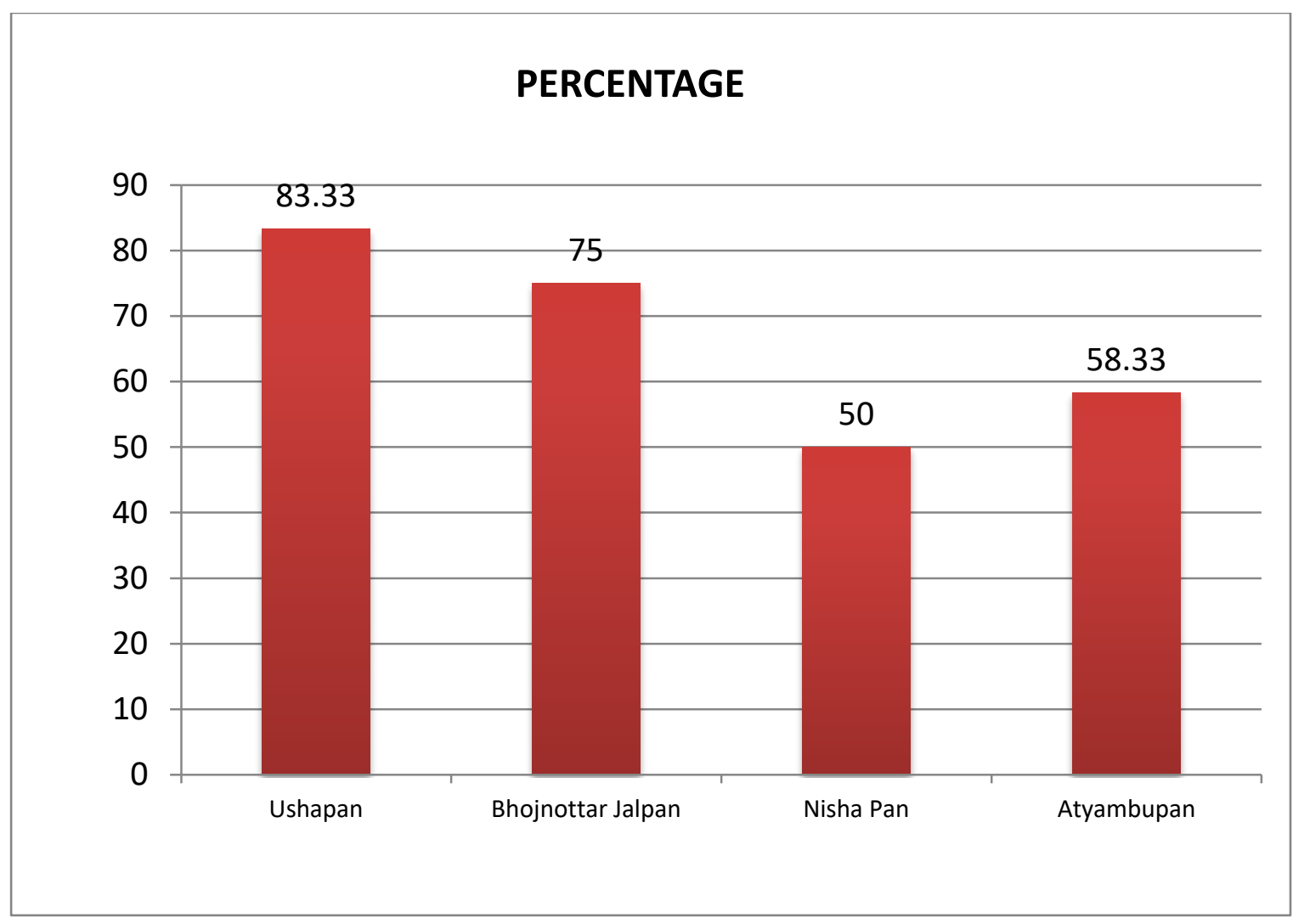

Patient's response to the treatment was evaluated on the basis of improvement in the sign and symptoms of the disease. The effect of treatment on symptoms in experimental group shows that prabhutamutrata got $82.35 \%$ relief, naktamutrata $75.86 \%$, awilmutrata 68.75\%, pipasa (pipasadhikya) $71.87 \%$, hastapadataldaha 75\%, gurugatrata $77.77 \%$, malalavibandh (malam Kaye) $67.64 \%$ and alasya (anutsysaha) $84.61 \%$ got the relief. Marked improvement was observed in the prabhuta mutrata, nakta mutrata, gurugatrata and alasya (anutsysaha). The moderate improvement was observed in symptoms like awilmutrata, pipasa(pipasadhikya), malalavibandh (malam kaye) and hastapadataldaha in experimental group . where as in control group, the symptoms like prabhutamutrata got $68.42 \%$ relief, awilmutrata $58.82 \%$, naktamutrata $57.57 \%$, pipasa (pipasadhikya) $60.71 \%$, hastapadataldaha 55\%, gurugatrata (sarvanga gaurava) $58.33 \%$ and alasya(anutsysaha) $61.53 \%$ showed relief which indicates moderate improvement in these symptoms. Less improvement was 
observed in malalavibandh (malam Kaye) $44.44 \%$ in the control group. The symptoms related to ama and shleshma dushti were prabhutamutrata, nakta mutrata, sarvanga gaurava, alasya showed marked relief in experimental group than control group.

In experimental group the mean of fasting blood sugar before treatment was 148 $\mathrm{mg} / \mathrm{dl}$ and after treatment $109 \mathrm{mg} / \mathrm{dl}$ while mean of postprandial blood sugar level before treatment was $210.61 \mathrm{mg} / \mathrm{dl}$ and after treatment $159.9 \mathrm{mg} / \mathrm{dl}$. In control group the mean of fasting blood sugar before treatment was $158.26 \mathrm{mg} / \mathrm{dl}$ and after treatment $117.46 \mathrm{mg} / \mathrm{dl}$ while mean of postprandial blood sugar level before treatment was $225.26 \mathrm{mg} / \mathrm{dl}$ and after treatment $175.33 \mathrm{mg} / \mathrm{dl}$. The comparison of blood sugar levels showed that there was improvement in both the groups but there was not much marked difference in the values of both the groups. Further evaluation with long duration of treatment is required.

\section{DISCUSSION:-}

Many patients arriving at OPD though regularly taking the allopathic treatment for the diabetes were presenting with the symptoms of prameha. The blood sugar level reports shows the decline pattern but still the symptoms like prabhuta, awil, nakta mutrata, pipasadhikya, alasya, sarvanga gaurav, malavibandha were presented by the diabetic patients. A strong association was found between the vidhi virahit jalapan and the diabetic patients. Thus the vyadhipratyanik

treatment along with the vidhi vihit jalapan was advocated in the patients of diabetes.

Prameha is the santarpanothha and apathyanimittaj vyadhi, the excessive indulgence of the hetu causes tridosha prakopa especially kapha dosha resulting in bahudrava and abaddha shleshma. It in turn causes dushti of rasa, rakta, mansa, meda, majja, shukra, lasika, kleda, vasa and oja, which progress into agnidushti, amanirmiti, strotorodha and kledavrudhhi.

Nidanparivarjan or Hetu-aseva i.e etiological factors are responsible for the cause of different types of prameha should be avoided which is mentioned as the line of treatment and also mandatory for samprapti bhanga. ${ }^{10}$ The chikitsa especially the vidhi vihit jalpan was initiated according to references from samhita. Excessive water intake causes mandagni amanirmiti and sheshma, kleda vruddhi. ${ }^{11}$ Bhojanottar jalpana and nishapan causes shleshma vitiation and shleshma vruddhi. ${ }^{12} \quad$ Nishapan is mentioned as vishasama (toxic) leading to kleda vruddhi, shleshma vruddhi. Ushapana in ajirnavastha increases the kleda and leads to agnidushti. Amatravat jalapan is considered as toxic in nature and the matravat jalapan (judicious water intake) is like "amrutam" that means it is beneficial and healthy. Excess water intake generates ama, pipasadhikya, nidra, sarvang gaurav, alasyaa (anutsyaha) and malavibandha. ${ }^{13}$ Less water intake (according to thirst) is advised in diabetes. 14

Vidhi vihit jalapana was advice as having the action of amapachana, shleshmakshaya, agnideepana, kledashoshana which contributes in the samprapti bhanga. The abaddha kleda and meda get reduced. Thus reduces the samprapti of Prameha. 
Hence nidanaparivarjana proves to play an essential and important role in the treatment of diabetes. Thus to achieve samprapti bhanga the root cause was tried to eliminate by avoiding the jalasevana (Water intake) particularly at specific kala (time period).

The vyadhipratyanik chikitsa used in the treatment of prameha was Madhusudan vati and Aarogyavardhini vati. The Madhusudan vati is the proprietary medicine which contents Dhatri, Nisha and Shilajatu. Dhatri being pancharasatmaka is tridosha shamaka, vatanulomaka, rasyana in nature vrushya, ojovardhaka and pramehaghna. ${ }^{15}$ Nisha and Shilajatu have tikta rasa, katu vipak, ushna veerya. Nisha is Kaphapittaghna, Lekhaniya, Varnya, Raktadoshahara, Vishghna and Pramehahara. Shilajatu is rasayana (rejuvenator), anti-ageing, tridoshaghna, dhatudardhyakar, malachedkar, mutra rogaghna, medo rogaghna and pramehaghna. Aarogyavardhini is having action as deepan, pachan, pathyakara, hruddya, medovinashini, malashuddhikar (kledaghna),kshutpravartini and also useful in all diseases. The properties of these medicines as tridoshamana, deepan, amapachana, kledanashak and rasayana. It helps in samprapti bhanga by normalizing the dosha and reducing the dhatushaithilya. It also improves the quality of dhatus, reduces the dravata and abaddhata of shleshma and meda. Thus reduces the symptoms of premeha. The combination of vyadhipratyanik chikitsa with nidanparivarjan gain the better results in less period of time.

\section{CONCLUSION:-}

Consideration of matra as well as kala is important while consumption of water intake. There is an association between jalapan and prameha. Vidhi vihit jalapan plays an important role in the treatment of diabetes. Less quantity of water consumption is advised in diabetes which is beneficial. Hence correction in style (that is frequent practice) is necessary for the treatment of lifestyle disorders.

SCOPE FOR THE STUDY: - Results of this small scale study are encouraging. There is further scope to carry out the present study with the bigger sample size, for longer duration and by evaluating the parameters like HbA1c.

\section{REFERENCES:-}

1. Global status report on noncommunicable diseases 2010. Geneva, World Health Organization, 2011.

2. Dr.Shivprasad

Sharma,Dravdravyavidyaniya,6/1014, Sutrasthana, Ashtanga samgraha of Vruddhavagbhata with Sasilekha Sanskrit Commentary by Indu , Chaukhamba Sanskrit Series, Varanasi, IV ${ }^{\text {th }}$ Edition,2016, Pg 35

3. Vaidya Yadvaji Trikamji Acharya, Rasaviman Adhaya 1/21,Viman sthana, Charak Samhita of Agnivesha elaborated by Charaka and Drudhabala with Ayurvedadipika commentary by Chakrapanidutta,Chaukhamba

Surbharati Prakashan, Varanasi, Reprint 2009,Pg 235

4. Vaidya Yadvaji Trikamji Acharya, Pramehanidan Adhaya 4/3 Tika,Nidan sthana,Charak Samhita of Agnivesha elaborated by Charaka and Drudhabala with Ayurvedadipika commentary by Chakrapanidutta,Chaukhaba Surbharati Prakashan, Varanasi,Reprint 2009,Pg 211

5. Vaidya Yadvaji Trikamji Acharya, Pramehanidan Adhaya 4/4 Tika,Nidan Sthana,Charak Samhita 
of Agnivesha elaborated by Charaka and Drudhabala with Ayurvedadipika commentary by Chakrapanidutta,Chaukhaba

Surbharati Prakashan, Varanasi, Reprint 2009,Pg 212

6. Vaidya Yadvaji Trikamji Acharya,Pramehachikitsitam

Adhaya 6/4,Chikitsa sthana, Charak Samhita of Agnivesha elaborated by Charaka and Drudhabala with Ayurvedadipika Commentary by

Chakrapanidutta,Chaukhaba

Surbharati Prakashan, Varanasi,Reprint 2009,Pg 445

7. Vaidya Yadvaji Trikamji Acharya ,Pramehanidan Adhaya 4/6-7,Nidan sthana, Charak Samhita of Agnivesha elaborated by Charaka and Drudhabala with Ayurvedadipika Commentary by Chakrapanidutta,Chaukhaba

Surbharati Prakashan ,Varanasi,Reprint 2009,Pg 212

8. Dr.Ganesh Krushna Garde, Pramehanidan Adhaya 10/7, Nidan sthana, Ashtanahrudaya of Vaghbhat marathi translation, Sarth vagbhat, Anmol Prakashan, Pune, Reprint 2003,Pg 191

9. 9.Vd. Yadavji Trikamji Acharya,Pramehanidan

Adhyaya,4/47, Nidan sthana, Caraka Samhita by Agnivesa elaborated by Caraka and Drudhabala with Ayurvedadipika commentary of Shri. Cakrapanidatta , Chaukhamba Surbharati Prakashan, Varanasi, Edition 2011,Pg 215
10. Vaidya Yadvaji Trikamji Acharya, Pramehachikitsitam Adhaya 6/53, Chikitsa sthana, Charak Samhita of Agnivesha elaborated by Charaka and Drudhabala with Ayurvedadipika commentary by Chakrapanidutta, Chaukhaba Surbharati Prakashan ,Varanasi,Reprint 2009, Pg 449

11. Shri. Bramhashankar Shashtri, Shitoshnavariguna,

$1 / 2$,Yogratnakar with Vidyotini hindi commentary by Shri.Laxmipati Shashtri, Chaukhamba Sanskrit Sansthan,Varanasi, VII th Edition 2002, Pg 95

12. Shri. Brahmashankar Mishra and Shri. Rupalalaji Vaishya,Dincharyadiprakaranam,5/ 158-159, First Part, Bhavprakash edited with Vidyotini commentary, Chaukhamba Sanskrit Sansthan,Varanasi, IX th Edition 1999, Pg 129

13. 13.Dr.Shivprasad Sharma, Dravdravyavidyaniya, 6/11-13, Sutrasthana, Ashtanga samgraha of Vruddhavagbhata with Sasilekha Sanskrit commentary by Indu , Chaukhamba Sanskrit Series, Varanasi, IV ${ }^{\text {th }}$ Edition,2016, Pg 37

14. http://niimh.nic.in/ebooks/eNighantu/bhavaprakashanighantu, Mishraprakaranam, Varivarga, 67

15. http://niimh.nic.in/ebooks/eNighantu/bhavaprakashanighantu, Mishraprakaranam, Haritakyadivarga, 36-37.

\section{Cite this article:}

"Role of jalapan in the samprapti and vidhi vihit jalapan in the management of prameha w.s.r. to type ii diabetes mellitus." Anjali A. Deshpande, Archana A. Kulkarni Ayurlog: National Journal of Research in Ayurved Science- 2020; (8) (3):01-09 